\title{
Jean Paul's
}

\section{fảmmtlide Werke.}

Dietnitoswansigfter Pano. 



\section{Jean Jaur's}

\section{「ä̉mitlide Đerke.}

Dritte vermebrte $\mathfrak{Z}$ uflage.

Dierunoziwanzigfter Band.

Berlin.

Berlag yon G. Retwer,

1862 
